\title{
Crotch angle formation in young apple trees grown in reversed position
}

Formowanie się kątów rozwidleń młodych drzewek jabłoni rosnących w pozycji odwróconej

\section{LESZEK S. JANKIEWICZ}

\section{INTRODUCTION AND LITERATURE}

It was shown previously ( $\mathrm{J}$ a n k i e w i c z, 1956, 1964) that the crotch angle between a young branch and the main axis of apple tree enlarges rapidly when a branch is not yet lignified. Later on the process of crotch angle formation slows down, and stops at the beginning of the summer. According to M ü n ch (1938), V e rn e r (1955) and K a ld e w e y (1962), the changes in the crotch angle width may be explained by differential elongation rate of the tissues situated on the upper and lower side of the branch. When the tissues on the upper side are growing faster (epinasty) - the crotch angle enalarges. When the tissues on the opposite side are growing faster, the crotch angle diminishes and the branch bends geotropically upward.

It was shown, however, ( $\mathrm{J}$ a n k i e w i c z 1964), that the crotch angle enlarges even in the case when geotropism and geoepinasty are not involved. For instance the crotch angle of a branch situated laterally on the trunk of horizontally grown tree enlarges in horizontal plane i.e. perpendicularly to the gravity. That is why $\mathrm{Jankiewicz} \mathrm{(1964)} \mathrm{put}$ forward the hypothesis that the gradual deviation of a branch from the trunk is caused by the mechanical pressure exerted on the branch base by the tissues situated in the crotch.

It seemed therefore interesting to verify that hypothesis with reversed trees.

\section{MATERIAL AND METHODS}

One-year-old non branched trees of two varietes 'Starking' and 'McIntosh' were potted in the autumn of 1961 in tin pails painted-inside. They were kept out of doors during the winter, their roots being pro- 


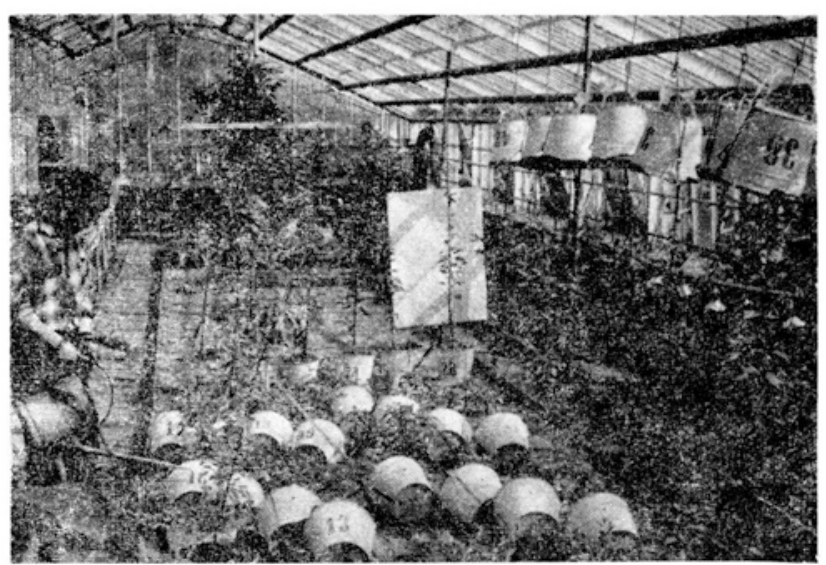

Fig. 1. General view of the experimental trees

tected against excessive freezing. After overwintering the trees were grown in different position toward the gravity. Some of them were ringed or decapitated since it was shown previously (J a n kiewic z 1956, 1964) that the first two or three branches below the ring or below the decapitation point exhibited strong geotropic bending whereas the other branches were plagiotropic.

'Starking' trees were transferred to the greenhouse in early March and were divided into the following groups (Fig. 1):

1. the non ringed trees grown in normal, vertical position. 3 trees

2. ringed trees grown in normal, vertical position . . . . 3 trees

3. reversed (upside down) trees, non ringed . . . . . . 4 trees

4. reversed (upside down) trees, ringed . . . . . . . . 4 trees

5. horizontally grown, non ringed . . . . . . . . . . 4 trees

6. horizontally grown, ringed . . . . . . . . . . . . 4 trees

The trees growing in the normal, vertical position will be named further ,vertical trees".

The crotch angles, the curvatures of the branches, the length of the branches and the number of leaves were measured several times during the first two months of growth. For the method of measurements see J a n kiewicz (1964).

The trees of 'McIntosh' variety were grown all the time in the open. In mid April they were decapitated about $15 \mathrm{~cm}$ below the apex. The trees were treated in three different ways:

1. grown in normal vertical position. . . . . . . . . 5 trees

2. grown in reversed (upside down) position . . . . . . 5 trees

3. grown in horizontal position . . . . . . . . . . . 6 trees

The measurements were made at $9-11$ days intervals, in the similar way as in the case of 'Starking' trees. The curvatures were measured 
on May 17th and on May 28th (it is 30 and 41 days after bud bursting) and only in the shoots longer than $3 \mathrm{~cm}$. In order to simplify the description of the results the shoots of 'McIntosh' trees were classified into several groups according to their position on the tree:

Group 1 the first and the second shoot (counted from the decapitation point),

Group 2 the third and the fourth shoot,

Group 3 the shoots 5 th to 10 th,

Group 4 the shoots 11 th to 16 th.

The results of the experiment with 'McIntosh' trees were worked out statistically with the method of analysis of variance using "t" test for significance.

\section{RESULTS}

'Starking' variety: There was a great variation in elongation rate as well as in the total length of the lateral shoots on the non ringed trees; it was so regardless of the position in which a tree was grown. There were growing side by side strong branches with numerous long $(20-40 \mathrm{~mm})$ internodes and very weak branches with only $1-3$ leaves and with very short internodes (about $1-5 \mathrm{~mm}$ ). In horizontal trees the weak branches were always situated on the lower side of the main axis and the strong branches on the upper and lateral sides.

The crotch angles of very weak branches in non ringed trees were usually very small $5-30^{\circ}$ (Fig. 2), regardless of the position of a tree. The crotch angles of the strong branches were large (Fig. 3), those in the reversed (upside down) trees being larger than in the ,vertical” or „horizontal” trees. The branches of „upside down" trees were curved geotropically much more than the branches of vertically or horizontally grown trees.

Ringing influenced to a great extent both the growth of the laterals and their crotch angles. The shoots situated just below (proximally to) the ring, were very vigorous, whereas those above (distally to) the ring were very weak. This pattern of growth was found in all ringed trees regardless of their position.

The crotch angles of the first two branches situated just below (proximally to) the ring were rather small in all trees. On the contrary the branches 5th to 8th below the ring had large crotch angles (Fig. 4).

The first and the second branches below the ring exhibited much stronger geotropic curvatures than the other branches. Those curvatures were, however, especially strong in the „upside down" trees and were very weak in „vertical” trees. 


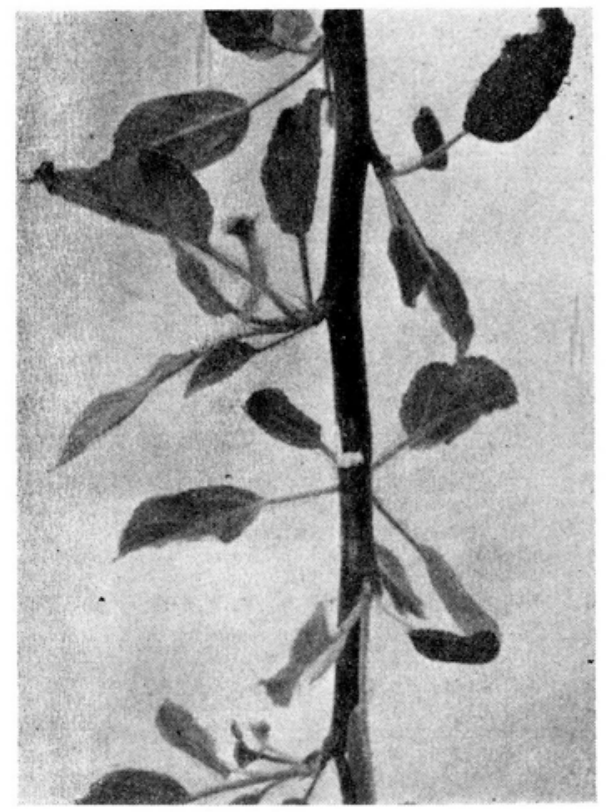

Fig. 2. In reversed by $180^{\circ}$ non ringed 'Starking' trees the weak branches bearing only $1-4$ leaves preserved small angles during the whole season

Above (distally to) the ring the crotch angles of very weak branches were small $\left(5-30^{\circ}\right)$ and those of stronger branches i.e. having more than about 4 leaves were large. The trees grown in different positions did not differ in this respect.

Fig. 3. Non ringed 'Starking' trees - the "strong" shoots (longer than

$$
2 \mathrm{~cm} \text { ) }
$$

$a-$ The average length of the shoots and $b$ - their crotch angle. The trees grown in normal, vertical position "V", in reversed "R" or in horizontal "H" position

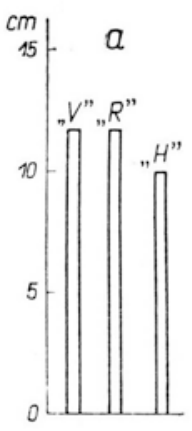

$b$

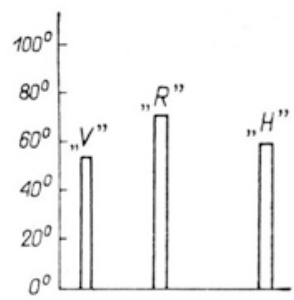

'M c Intosh' variety. There were not very pronounced differences in shoot length between the trees grown in different positions. The average length of the branches is shown in the Fig. 6a. In all trees: ,vertical”, as well as „horizontal” and „reversed” the first four apical branches were the strongest.

In all 'McIntosh' trees the crotch angles enlarged gradually during 
In , $\mathrm{H}$ " trees $\mathrm{C}_{0}$ was measured in horizontal plane and the curvatures $\left(\mathrm{C}_{1}-\mathrm{C}_{4}\right)$ in vertical plane
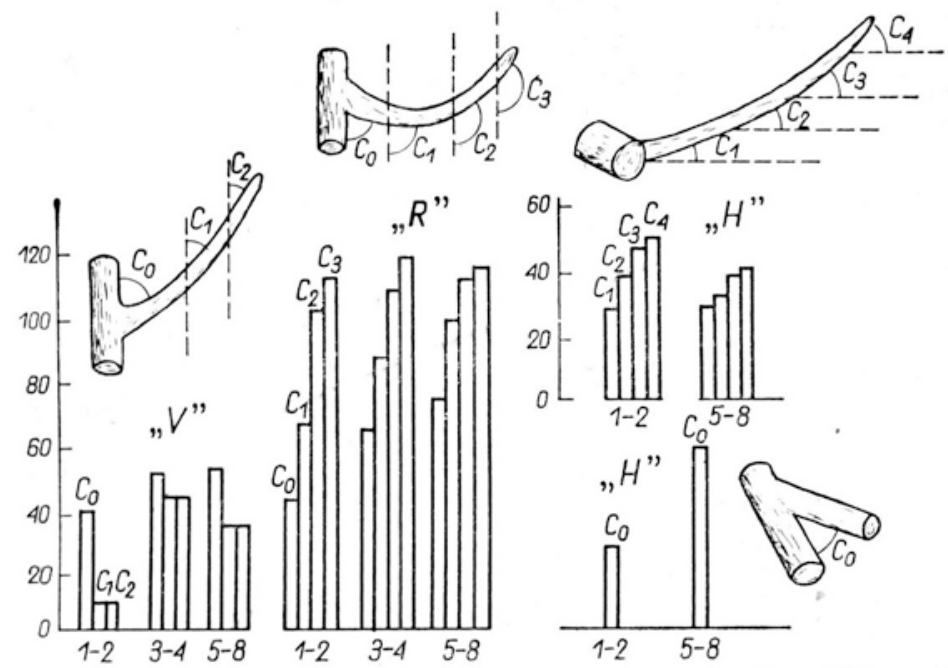

Fig. 4. 'Starking' ringed trees: the crotch angles $\left(\mathrm{C}_{0}\right)$ and the curvatures of the branches $\left(\mathrm{C}_{1}-\mathrm{C}_{\text {: }}\right)$

On the abscissa the groups of the branches: the first and the second branch situated below (proximally to) the ring, 3-rd and 4-th, and 5-th to 8-th branches. The meaning of ,V", , $\mathbb{R} "$, and ,H" as in fig. 3 .

the period from April 28th (about a week after bud bursting) to May 28th (the date of last measurement, Fig. 6b). It was found in all trees that the more proximally situated a branch the larger was its crotch

Fig. 5. 'Starking' ringed trees: length of the branches situated below (proximally to) the ring after

6 weeks of growth

For other details see fig. 3 and 4

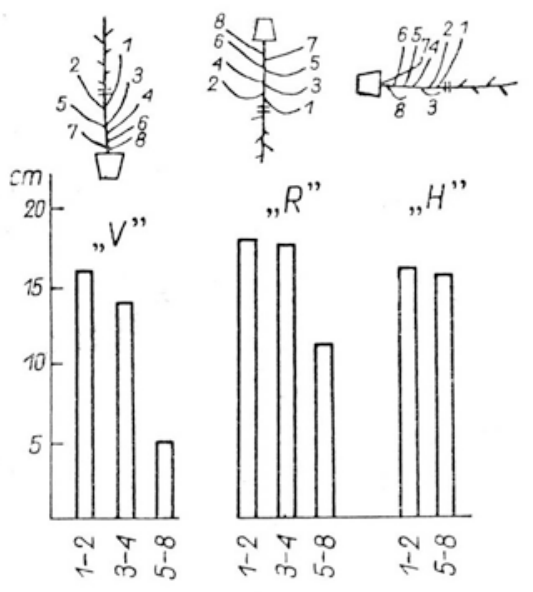

angle. It is a normal phenomenon for ,vertically" grown trees ( $\mathrm{J}$ a nkiewicz 1957), but it was interesting to find it also in the trees reversed by $180^{\circ}$.

The crotch angle width of four branches situated most distally on a tree varied markedly depending on the position in which the tree 
was growing (Fig. 6b). Those crotch angles were the smallest in vertically grown trees and were the largest in the trees grown in ,upside down" position (differences were significant on all dates of measurements). Those four most distally situated branches exhibited also strong geotropic bending (especially first and second branch). They bent upward,
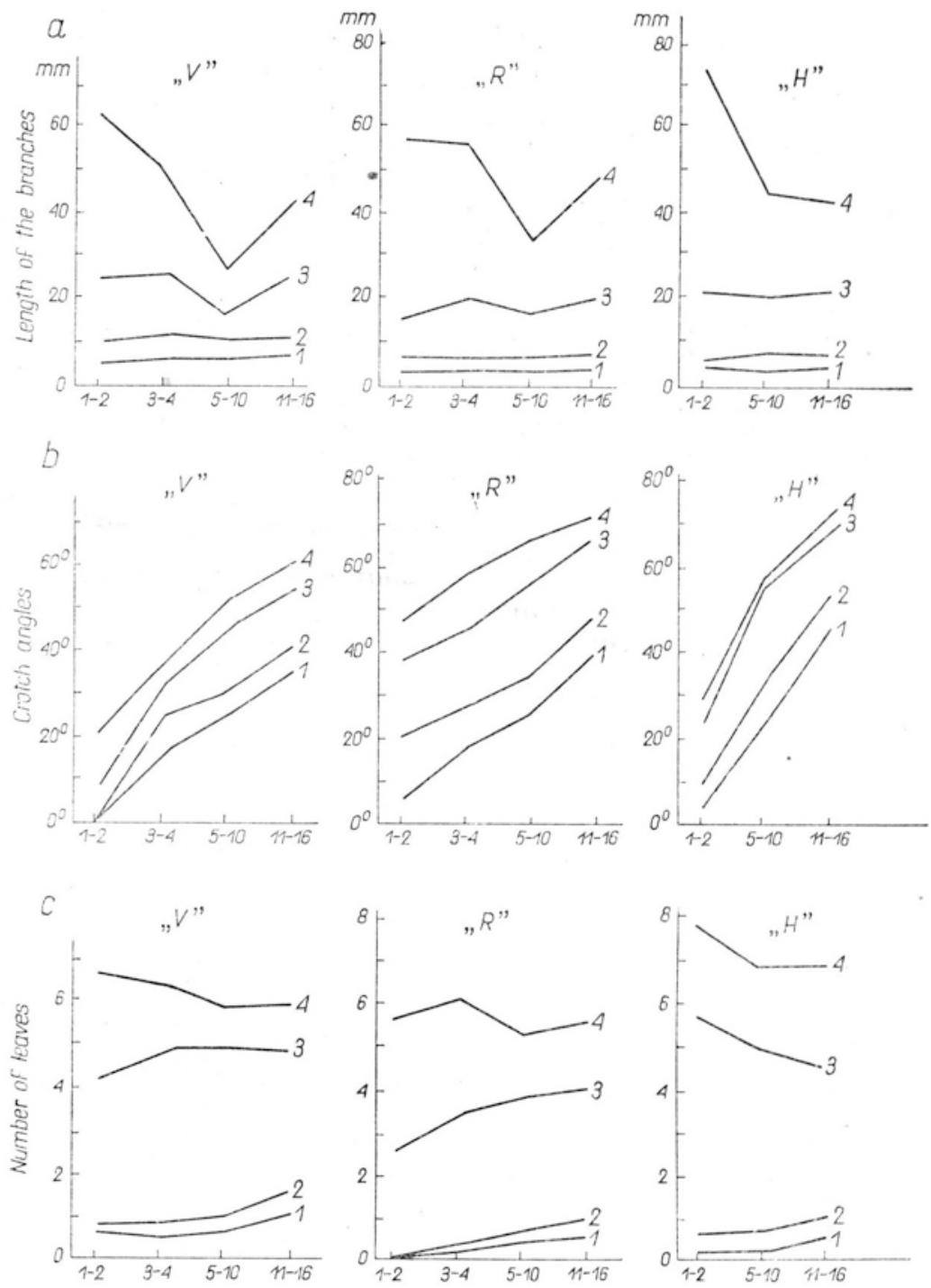

Fig. 6. 'McIntosh' decapitated trees grown in vertical "V", reversed "R"or horizontal "H" position

$a$ - length of the branches; $b$ - crotch angles; $c$ - number of leaves of the branches. On the abscissa the groups of the branches (as explained in methods). In horizontally grown trees only the branches situated laterally on the trunk were taken into account

1 - April 28-th, 2 - May 7-th, 3 - May 17-th and $4-$ May 28-th 


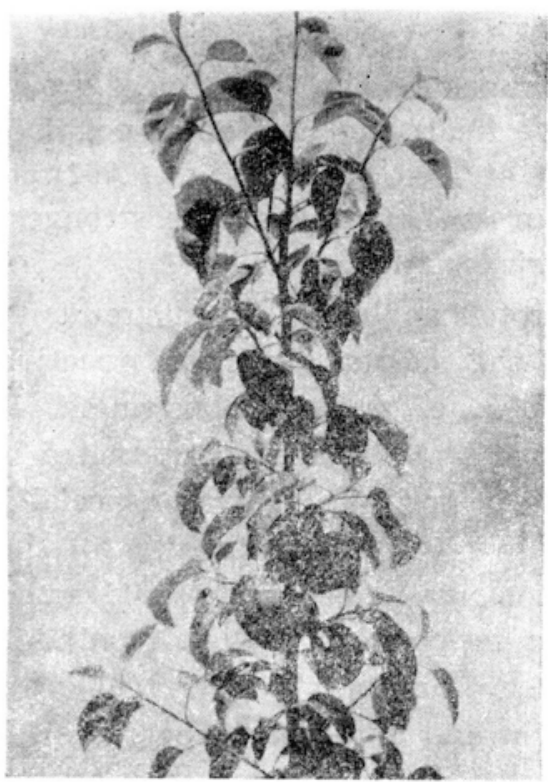

a

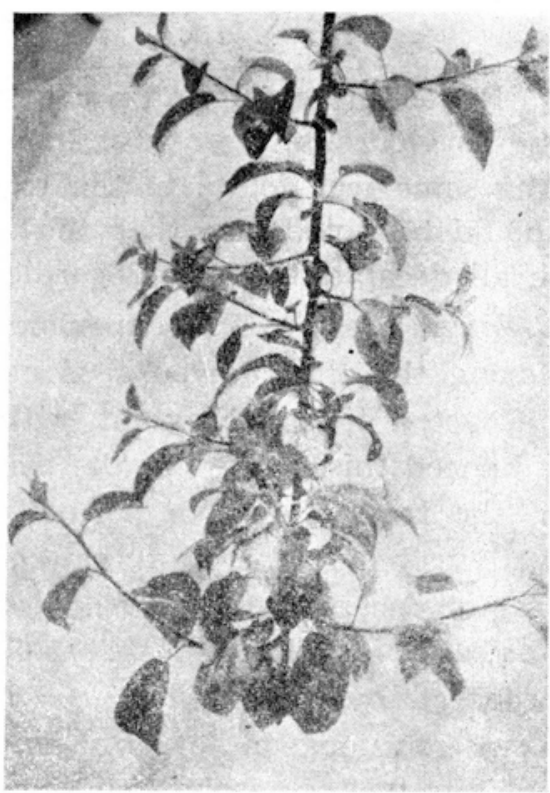

C

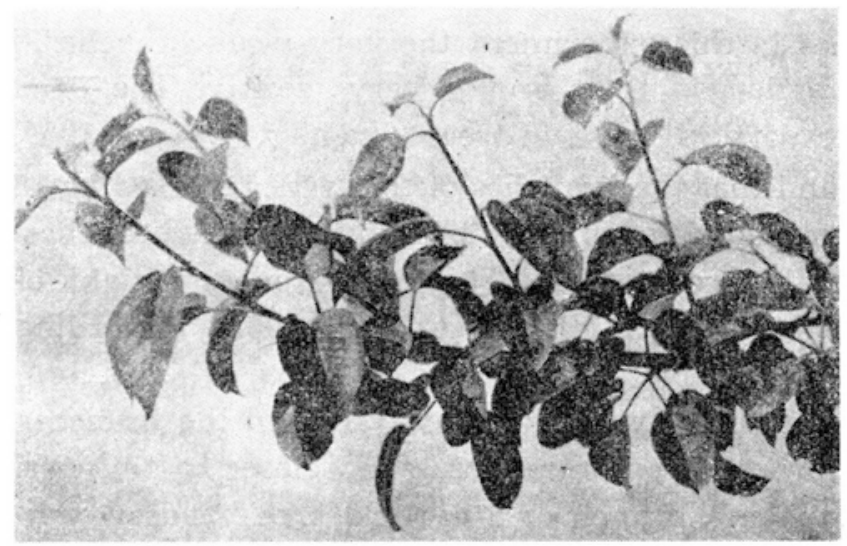

b

Fig. 7. 'McIntosh' decapitated trees after a month of growth $a$ - The trees grown in vertical; $b-$ horizontal and $c$ - reversed positions. In horizontally grown trees the apical branches first and second were situated always laterally on the trunk.

what was especially well visible in reversed trees (Fig. 7). The geotropical bending of the branches 5 th to 10 th and 11th to 16 th was often non perceptible in vertically grown trees, but it was very distinct in the trees grown in reversed position. In the trees grown in horizontal position those branches were slightly geotropically curved upward near their base but their further parts were straight or even epinasticly bent downward. 


\section{DISCUSSION}

It was interesting to find out that the ,upside down" trees were growing as vigorousely as those in normal (vertical) and horizontal position. The same was found in the experiment at East Malling (1962). It should be noted also that the apical four branches were the strongest in all decapitated trees regardless of their position.

In all trees in this experiment the crotch angles enlarged gradually during the first 6 weeks of growth of the shoots. Geotropic reaction interacted to some extent with the course of crotch enlargement. It enhanced this process in the trees reversed by $180^{\circ}$ and counteracted it in the trees grown in normal i.e. vertical position. It was especially well visible in the first two shoots situated below (proximally to) the ring or decapitation point i.e. in which geotropism was not counteracted markedly by the geoepinasty. Those facts support the earlier hypothesis proposed by Jankiewicz (1964) according to which crotch angle formation depends not only on geotropism and geoepinasty of a branch but also on the mechanical pressure exerted on the branch base by the tissues situated in the crotch.

In all trees in this experiment the very weak branches, bearing only 1-4 leaves, enlarged their angles very weakly. The same was noted earlier in the vertically grown trees ( $\mathrm{J}$ a n k i e w i c z 1964).

It was found that the branches of the trees reversed by $180^{\circ}$ exhibited much more pronounced geotropic bending than the branches of vertically and horizontally grown trees. Those differences maight be partly explained with the sine rule ( $\mathrm{R}$ a w it $\mathrm{ch}$ e $\mathrm{r}$ 1932). According to that rule the strongest geotropic induction takes place when a branch occupies perpendicular position with the gravity. When the branch of a reversed tree bends upward it becomes closer and closer to this position. On the contrary - when a branch of a vertical tree bends upward it deviates from the angle $90^{\circ}$ with gravity and approaches more and more the angle $0^{\circ}$ where geotropical induction is zero.

\section{SUMMARY}

Crotch angle formation was investigated in the apple trees grown in the position reversed by $180^{\circ}$. The trees grown in vertical as well as those in horizontal position were also taken for comparison. One-year-old 'Starking' and 'McIntosh' trees were studied, some of them being ringed and some other decapitated.

In all investigated trees the crotch angles were increasing gradually during the first $4-6$ weeks of growth of the branches. Geotrop:sm and geoepinasty interacted with the process of crotch enlargement to some extent.

The results obtained coincide well with author's earlier hypothesis according 
to which the crotch angle width depends not only on geotropism and geoepinasty but also on mechanical pressure exerted on the base of a young branch by the increasing in volume tissues situated in the crotch.

The research was supported by U.S. Department of Agriculture, Agricultural Research Service, Grant No. FG-Po-111.

\section{Research \\ Institute of Pomology}

Skierniewice, Poland

(Entered: 28.4.1965)

\section{STRESZCZENIE}

Badano zjawisko formowania się kątów rozwidleń w drzewkach odmiany 'Starking' i 'McIntosh' w drugim roku po okulizacji, umieszczonych w pozycji odwróconej o $180^{\circ}$ (do góry korzeniami). Dla porównania wzięto również drzewka rosnące w pozycji pionowej (normalnej) i poziomej. Niektóre drzewka obrączkowano, a inne ogławiano lub pozostawiano z nie uszkodzonym wierzchołkiem.

We wszystkich drzewkach kąty rozwidleń powiększały się stopniowo w czasie pierwszych 4-6 tygodni wzrostu gałązek. Geotropizm i geoepinastia modyfikowały ten proces w pewnym stopniu; na przykład w drzewkach odwróconych geotropijna reakcja ułatwiała odchylanie się gałązek od pnia, a w drzewkach rosnących w pozycji pionowej utrudniała.

Otrzymane wyniki zgadzają się z wcześniejszą hipotezą autora, że wielkość kątów rozwidleń zależy nie tylko od geotropizmu i geoepinastii, lecz przede wszystkim od ciśnienia mechanicznego wywieranego na młodą gałązkę przez tkanki rozrastające się w rozwidleniu i powodujące odchylanie się jej od pnia.

\section{LITERATURA}

1. East Malling Res. Sta. Ann. Rep. for 1962 (see also Mullins 1965).

2. Jankiewicz L., 1956, The effect of auxins on crotch angles in apple trees, Bull. Acad. Polon. Sci. Cl. II 4(5):173-178.

3. J a nkiewicz L. S., 1957, Wpływ auksyn na formowanie się kąta rozwidlenia u jabłoni, Doctoral Thesis, Szkoła Główna Gosp. Wiejsk., Warszawa.

4. Jankiewicz L. S., 1964, Mechanism of the crotch angle formation in apple trees I. The crotches in the trees growing in a vertical and horizontal positions, Acta Agrobot., 15:21-50.

5. K a ldewey H., 1962, Plagio- und Diageotropismus der Sprosse und Blaetter einschlieslich Epinastie, Hyponastie, Entfaltungbewegungen. Handbuch der Pflanzenphysiologie. Bd. 17:200-321, Springer Verlag, Berlin.

6. Mullins M. G., 1965, The Gravitational Responses of Young Apple Trees, J. Horti Sci. 40:237-297.

7. M ünch E., 1938, Untersuchungen ueber die Harmonie der Baumgestalt, Jb. wiss. Bot. $86: 581-673$.

8. R aw its cher F., 1932, Der Geotropismus der Pflanzen, Gustav Fisher, Jena.

9. Verner L., 1955, Hormone relations in the growth and training of apple trees, Univ. Idaho Agr. Exp. Sta. Res. Bul. 28:1-31. 